\title{
Biologically Active Low Density Lipoprotein in Human Peripheral Lymph
}

\author{
D. Reichl and N. B. Myant, Medical Research Council, Lipid Metabolism Unit, \\ Hammersmith Hospital, London, England \\ Michael S. Brown and Joseph L. GoldSTein, Department of Internal Medicine, \\ University of Texas Health Science Center at Dallas, Dallas, Texas 75235
}

\begin{abstract}
A B S T RACT We have compared the ability of human serum and peripheral lymph to suppress the activity of 3-hydroxy-3-methylglutaryl-coenzyme A reductase (HMG-CoA reductase), to activate cholesteryl ester synthesis, and to compete with ${ }^{125}$ I-labeled low density lipoprotein (LDL) for binding to LDL receptors in cultured human fibroblasts. Whole lymph was active in all three tests and the activity per unit volume in lymph was $\cong 1 / 10$ th that in serum. All three biologic activities in lymph were confined to the $d<1.063 \mathrm{~g} / \mathrm{ml}$ fraction. Whole lymph had no significant effect on HMG-CoA reductase activity in fibroblasts from a patient with homozygous familial hypercholesterolemia, whose cells lack LDL receptors. The LDL-like biologic activity per unit mass of immunologically active apoprotein B was approximately the same in lymph as in serum. The current data indicate that functionally active LDL is present in lymph and that the concentration of this lipoprotein is $\cong 1 / 10$ th that in serum.
\end{abstract}

\section{INTRODUCTION}

A class of plasma proteins, including transcobalamin II, transferrin, and low density lipoprotein (LDL), ${ }^{1}$ transport nutrient molecules (i.e. vitamin $B_{12}$, iron, and cholesterol, respectively) from their tissues of origin to their tissues of utilization. In delivering these nutrient molecules to cells, the protein carriers bind to specific receptors on cell surfaces $(1-5)$. To reach these cellular receptors from the plasma, the proteins

Dr. Brown is an Established Investigator of the American Heart Association.

Received for publication 20 July 1977 and in revised form 2 September 1977.

${ }^{1}$ Abbreviations used in this paper: $\mathrm{FH}$, familial hypercholesterolemia; HMG-CoA reductase, 3-hydroxy-3-methylglutaryl-coenzyme A reductase; LDL, low density lipoprotein; VLDL, very low density lipoprotein. must first pass through the capillary wall and enter the interstitial fluid that is in contact with the cells. Extensive studies indicate that the capillary endothelium forms a permeability barrier to the passage of such macromolecules $(6,7)$. In lymph, whose composition is believed to reflect the composition of interstitial fluid (6), the concentration of a given macromolecule relative to its concentration in plasma is reduced in all cases thus far investigated $(8,9)$.

Studies have shown that a capillary permeability barrier exists for human plasma LDL (10-12), a lipoprotein whose molecular weight approaches $3 \times 10^{6}$ (13). In human lymph obtained from the dorsum of the foot, the concentration of apoprotein $\mathrm{B}$, the major protein component of LDL (13), is $\cong 10 \%$ of that in plasma when measured by immunologic techniques (12). Moreover, $14 \mathrm{~h}$ after an intravenous infusion of ${ }^{131}$ I-labeled LDL to human subjects, the concentration of radioactivity present as LDL-protein in the lymph was found to be $\cong 1 / 10$ th that in the plasma (11). The existence of this concentration gradient for plasma LDL implies that body cells must possess a mechanism that is capable of interacting with LDL when the lipoprotein is present in a concentration $1 / 10$ th that in plasma.

At the same time that the measurements of LDL levels in human lymph were performed, studies in cultured human fibroblasts revealed that these cells do in fact possess a high affinity cell surface receptor that allows them to bind LDL when the lipoprotein is present at low concentrations $(14,15)$. Binding of LDL to the receptor is followed by uptake of the lipoprotein through adsorptive endocytosis, hydrolysis of both its protein and cholesteryl ester components in lysosomes, and transfer of the hydrolyzed cholesterol into the cellular compartment where it exerts three regulatory actions: $(a)$ it suppresses the activity of 3-hydroxy-3-methylglutaryl-coenzyme A reductase (HMG-CoA reductase), thereby reducing 
TABLE I

Clinical Characteristics of Subjects Providing Lymph

\begin{tabular}{|c|c|c|c|c|c|c|c|c|}
\hline \multirow{3}{*}{$\begin{array}{l}\text { Sub- } \\
\text { ject }\end{array}$} & \multirow[b]{3}{*}{ Age } & \multirow[b]{3}{*}{ Sex } & & & \multicolumn{4}{|c|}{ Lymph } \\
\hline & & & \multicolumn{2}{|c|}{ Serum } & \multicolumn{2}{|c|}{ Cholesterol } & \multicolumn{2}{|c|}{ Apoprotein B } \\
\hline & & & Cholesterol & Apoprotein B & Free & esterified & Total & $\mathrm{d}<1.063 \mathrm{~g} / \mathrm{ml}$ \\
\hline & $y r$ & & $m g / d l$ & $\mu \mathrm{g} / \mathrm{ml}$ & \multicolumn{2}{|c|}{$\mu g / m l$} & \multicolumn{2}{|c|}{$\mu g / m l$} \\
\hline 1 & 23 & F & 217 & 1,100 & 92 & 166 & 70 & 一 $^{*}$ \\
\hline 2 & 24 & M & 221 & 910 & - & - & 85 & 78 \\
\hline 3 & 23 & F & 194 & 720 & 120 & 180 & $\{50 t$ & $\{40\rfloor$ \\
\hline 4 & 26 & $\mathbf{M}$ & 237 & 850 & 89 & 190 & & \\
\hline 5 & 51 & $\mathrm{~F}$ & 294 & 710 & 94 & 171 & 70 & - \\
\hline 6 & 23 & M & 271 & 840 & 100 & 170 & 95 & - \\
\hline 7 & 21 & $\mathrm{~F}$ & 178 & 750 & 57 & 117 & 115 & - \\
\hline
\end{tabular}

* No measurement made.

$\ddagger$ The lymph samples from the two subjects were pooled before assay of apo LDL.

cellular cholesterol synthesis; $(b)$ it activates a fattyacyl coenzyme A:cholesterol acyltransferase, thereby facilitating the esterification of excess cholesterol for storage; and $(c)$ it suppresses the synthesis of LDL receptors, thereby preventing excessive accumulation of cholesterol (reviewed in references 4 and 5). In addition to its presence in human fibroblasts, the LDL receptor has been identified in a variety of other culture cell types (5) as well as in freshly isolated human lymphocytes that have been incubated in the absence of lipoproteins (16).

In all of the above cell types, saturation of the LDL receptor at $37^{\circ} \mathrm{C}$ is achieved at an LDL concentration of $\cong 50 \mu \mathrm{g}$ protein $/ \mathrm{ml}(17)$, a value that is much lower than the concentration of LDL-protein normally found in plasma of Western man $(\cong 800 \mu \mathrm{g} / \mathrm{ml})$ $(12,13)$. This finding has suggested that the LDL receptor is adapted to function at the low levels of LDL present in interstitial fluid rather than at the higher levels present in plasma (17). In the current studies we have tested this hypothesis directly. Using the fibroblast system, we have compared the ability of whole serum, whole lymph, and lymph lipoprotein fractions to bind to the LDL receptor, to suppress HMG-CoA reductase activity, and to stimulate the esterification of cholesterol. The results indicate that lymph from the dorsum of the human foot contains biologic activity resembling that of plasma LDL and that the concentration of this activity is $\cong 10 \%$ of that in plasma.

\section{METHODS}

Materials. Sodium ${ }^{125}$ I-iodide (carrier-free in $0.05 \mathrm{~N}$ $\mathrm{NaOH})$ and $\left[1-{ }^{14} \mathrm{C}\right]$ oleic acid $(58 \mathrm{mCi} / \mathrm{mmol})$ were obtained from Amersham/Searle Corp. (Arlington Heights, Ill.). D,L3-hydroxy-3-[ methyl-3- $\left.{ }^{14} \mathrm{C}\right]$ Glutaryl-CoA $(26.2 \mathrm{mCi} / \mathrm{mmol})$ was purchased from New England Nuclear, Boston, Mass. Sodium dextran sulfate (mol wt $\cong 500,000)$ was obtained from Pharmacia (Fine Chemicals, Div. of Pharmacia Inc., Piscataway, N. J.). Tissue culture supplies, thin-layer chromatographic materials, and reagents for assays were obtained from sources as reported $(14,15)$. Materials used for the radioimmunoassay of apoprotein $B$ in lymph and serum were those described (12). The rabbit antiserum to human LDL was obtained from Behring-Werke AG (Marburg/ Lahn, West Germany).

Human subjects. Lymph was obtained from seven subjects by retrograde cannulation of a lymph duct in the dorsum of the foot as described (10). All except subject 5 were healthy young adults. Subject 5 , a Vietnamese woman, was suffering from chronic filariasis, with lymphedema of both legs. Other features of these subjects are listed in Table I. None of the subjects was taking any drugs known to influence lipid or lipoprotein metabolism. Informed consent to the cannulation was obtained from each subject.

Preparation of lipoproteins from subjects providing lymph. Lipoprotein fractions from serum and lymph obtained from the subjects listed in Table I were prepared by differential ultracentrifugation (18) in London and mailed to Dallas for biologic testing. ${ }^{2}$ Before shipment to Dallas, aliquots of the serum and lymph samples were removed for measurement of apoprotein B and cholesterol content. When sufficient lymph was available, free and esterified cholesterol concentrations were measured separately.

To eliminate the possibility of dilution of the growth medium constituents by the large volumes of lymph that had to be added to the culture dishes (see following text), some of the specimens of whole lymph, whole serum, and isolated lymph and serum fractions were dialyzed at $4^{\circ} \mathrm{C}$ for $24 \mathrm{~h}$ against a 500-fold excess of medium A (Eagle's minimal essential medium supplemented with penicillin [100 U/ml], streptomycin $[100 \mu \mathrm{g} / \mathrm{ml}] ; 20 \mathrm{mM}$ Tricine (California Biochemical Corp., Los Angeles, Calif.), pH 7.4; $24 \mathrm{mM} \mathrm{NaHCO}$; and $1 \%$ [vol/vol] nonessential amino

${ }^{2}$ Samples of serum and lymph were packed in a thermos bottle containing wet ice and were sent by air freight from London to Dallas. Four different shipments were made during the course of this study, and in each case the temperature of the samples upon arrival in Dallas was $2-4^{\circ} \mathrm{C}$. 
acids). Before dialysis, a tracer amount of ${ }^{125}$ I-LDL (800 cpm, $2.5 \mathrm{ng}$ ) was added to each lymph and serum sample to correct for losses of LDL during dialysis. In addition, each of these samples received human lipoproteindeficient serum to a final concentration of $10 \%$ (5 mg protein $/ \mathrm{ml}$ ) before dialysis. The recovery of ${ }^{125} \mathrm{I}-\mathrm{LDL}$ from the dialysis step averaged $71 \%$ for the lymph and $84 \%$ for the serum samples, and the data were corrected for this recovery. In the experiments shown in Figs. 1 and 2 , the whole lymph and whole serum specimens were used without dialysis into medium $A$, and the results were comparable to those obtained with the dialyzed samples.

Measurement of apoprotein B. Apoprotein B in whole serum, whole lymph, and isolated lymph fractions was assayed by quantitative immunoelectrophoresis with rabbit antiserum to human LDL as described (12). The concentration of apoprotein $B$ in the sample was estimated from the ratio of the height of the "rocket" formed by the sample to that of the rocket formed by a solution of serum LDL (d $1.020-1.050 \mathrm{~g} / \mathrm{ml}$ ) containing a known amount of protein assayed by the Lowry method with bovine serum albumin as standard.

Preparation of lipoprotein-deficient sera and standard $L D L$. Human (19) and fetal calf (20) lipoprotein-deficient sera $(d>1.215 \mathrm{~g} / \mathrm{ml})$ were prepared by ultracentrifugation and dialyzed as described in the referenced articles. Standard preparations of human LDL $(d 1.019-1.063 \mathrm{~g} / \mathrm{ml})$ were obtained from the plasma of individual healthy subjects and prepared by differential ultracentrifugation in Dallas (19). ${ }^{125}$ I-Labeled LDL was prepared as described (21).

Cells. Cultured fibroblasts were derived from skin biopsies obtained from normal subjects and a patient with the receptor-negative form of homozygous familial hypercholesterolemia (FH) (22). Cells were grown in monolayer and used between the 5th and 20th passage. Stock cultures were maintained in a humidified $\left(5 \% \mathrm{CO}_{2}\right)$ incubator at $37^{\circ} \mathrm{C}$ in $250-\mathrm{ml}$ flasks containing $10 \mathrm{ml}$ of medium $\mathrm{A}$ and $10 \%$ (vol/vol) fetal calf serum. All experiments were performed in a similar format. On day 0 , confluent monolayers of cells from stock flasks were dissociated with $0.05 \%$ trypsin-0.02\% EDTA solution, and $6 \times 10^{4}$ cells were seeded into each $35 \times 10 \mathrm{~mm}$ Petri dish containing $2 \mathrm{ml}$ of medium A with $10 \%$ fetal calf serum. On days 1 and 2 , the medium was replaced with $2 \mathrm{ml}$ of fresh medium A containing $10 \%$ fetal calf lipoprotein-deficient serum. Experiments were performed on day 3 after the cells had been incubated for $48 \mathrm{~h}$ in the presence of lipoprotein-deficient serum.

Receptor-binding of ${ }^{125}$ I-LDL by intact fibroblast monolayers at $4^{\circ} \mathrm{C}$. On day 3 , cell monolayers were cooled to $4^{\circ} \mathrm{C}$ for $30 \mathrm{~min}$. The medium was removed and each dish received a total of $0.6 \mathrm{ml}$ of ice-cold medium A containing $10 \%$ human lipoprotein-deficient serum, $2 \mu \mathrm{g}$ protein $/ \mathrm{ml}$ of ${ }^{125} \mathrm{I}-\mathrm{LDL}(270-370 \mathrm{cpm} / \mathrm{ng})$, and the indicated amounts of unlabeled lipoproteins, serum, or lymph. Cell monolayers were incubated for $2 \mathrm{~h}$ at $4^{\circ} \mathrm{C}$ on a rotary shaker $(60$ oscillations/min). Each monolayer was then washed six times at $4^{\circ} \mathrm{C}$ with an albumin-containing buffer (15), after which a $1-\mathrm{ml}$ solution containing sodium dextran sulfate $(4 \mathrm{mg} / \mathrm{ml})$ was added to each dish (15). The dishes were incubated at $4^{\circ} \mathrm{C}$ for $1 \mathrm{~h}$; the dextran sulfate-containing solution was removed; and an (0.8-ml) aliquot was placed in a welltype gamma counter to determine the total amount of ${ }^{125} \mathrm{I}$ LDL that had bound to the cell surface and was hence released by dextran sulfate into the supernatant solution (15). After the dextran sulfate wash, the cells were dissolved in $0.1 \mathrm{~N} \mathrm{NaOH}$ and an aliquot was used to determine the content of total cell protein (15). In all experiments, the average content of total cell protein was $75-100 \mu \mathrm{g} / \mathrm{dish}$.
Because of the limited amounts of lymph available, all detailed binding studies were performed at $4^{\circ} \mathrm{C}$. As reported (15), the affinity of the LDL receptor for LDL is $\cong 10$-fold higher at $4^{\circ} \mathrm{C}$ than at $37^{\circ} \mathrm{C}$. This 10 -fold higher affinity at $4^{\circ} \mathrm{C}$ permits competition studies to be performed with smaller volumes of lymph than would be required at $37^{\circ} \mathrm{C}$.

Assay of HMG-CoA reductase activity. On day 3, each monolayer received a total of $0.6 \mathrm{ml}$ of medium A containing $10 \%$ human lipoprotein-deficient serum and the indicated amounts of lipoproteins, serum, or lymph. After incubation at $37^{\circ} \mathrm{C}$ in a $\mathrm{CO}_{2}$ incubator for $16 \mathrm{~h}$, the cells were harvested, detergent-solubilized extracts were prepared, and the rate of conversion of 3-hydroxy-3-[methyl$\left.3-^{14} \mathrm{C}\right]$ glutaryl-CoA $(10,000 \mathrm{cpm} / \mathrm{nmol})$ to $\left[{ }^{14} \mathrm{C}\right]$ mevalonate was determined as described (19).

Incorporation of $\left[1-{ }^{14} \mathrm{C}\right]$ oleate into cholesteryl esters by intact fibroblast monolayers. On day 3, each monolayer received a total of $0.6 \mathrm{ml}$ of medium A containing $10 \%$ human lipoprotein-deficient serum, $0.1 \mathrm{mM}\left[{ }^{14} \mathrm{C}\right]$ oleatealbumin $(11,000 \mathrm{cpm} / \mathrm{nmol})$, and the indicated amounts of lipoproteins, serum, or lymph. After incubation at $37^{\circ} \mathrm{C}$ in a $\mathrm{CO}_{2}$ incubator for $16 \mathrm{~h}$, the cells were harvested, extracted with chloroform/methanol, and the cholesteryl $\left[{ }^{14} \mathrm{C}\right]$ oleate was isolated by thin-layer chromatography and quantified as described (23).

Other assays. The protein content of serum, lymph, and plasma LDL was determined by the method of Lowry et al. (24) with bovine serum albumin as standard. The protein content of fibroblast extracts was determined by the Lowry method after precipitation in $10 \%$ trichloroacetic acid. Cholesterol was assayed by the gas-liquid chromatographic method of Blomhoff (25) with $5 \alpha$-cholestane as standard. Free and esterified cholesterol were separated by thin-layer chromatography before assay.

\section{RESULTS}

Fig. 1 compares the ability of varying volumes of whole serum and whole lymph (obtained from subject 1) to suppress HMG-CoA reductase in human fibroblasts. To perform these studies, the fibroblasts were first incubated for $48 \mathrm{~h}$ in the absence of lipoproteins so as to induce high levels of HMG-CoA reductase activity (19). For whole serum and whole lymph, the degree of suppression of HMG-CoA reductase activity was proportional to the logarithm of the volume added over a wide range. When lines were fitted to the data points by the method of least squares, the slopes were similar $(-66.7$ for whole serum and -59.6 for whole lymph). However, the suppression line for whole lymph was displaced to the right of that for whole serum, indicating that a 10-fold higher volume of whole lymph was required to achieve the same degree of suppression as that achieved by a given volume of whole serum.

These data suggested that whole lymph contained material capable of binding to the LDL receptor of fibroblasts and delivering cholesterol to the cells so as to suppress HMG-CoA reductase activity. To demonstrate the presence of material that bound to the LDL receptor, fibroblasts were incubated with ${ }^{125}$ I-LDL 


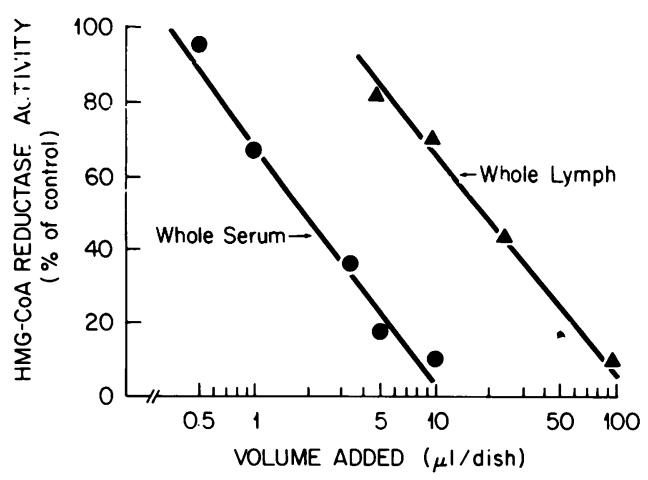

FIGURE 1 Comparison of the ability of whole serum (O) and whole lymph $(\Delta)$ to suppress HMG-CoA reductase activity in normal fibroblast monolayers. The serum and lymph were obtained from subject 1 and incubated with the cells for $16 \mathrm{~h}$ at $37^{\circ} \mathrm{C}$ as described under Methods except that the serum and lymph specimens were not dialyzed into medium A. All samples were diluted to a $100 \mu \mathrm{l}$ volume in buffer $\mathrm{A}(0.15 \mathrm{M} \mathrm{NaCl}$ and $0.3 \mathrm{mM}$ EDTA, $\mathrm{pH} 7$ ) before being added to the $0.5 \mathrm{ml}$ of growth medium in the culture dish. HMG-CoA reductase activity was determined as described under Methods. Each point represents the average of duplicate dishes except for the $100-\mu l$ whole lymph point, which was a single dish. The $100 \%$ of control value for HMG-CoA reductase (mean of triplicate dishes) was $175 \mathrm{pmol} / \mathrm{min}$ per $\mathrm{mg}$ protein.

at $4^{\circ} \mathrm{C}$ in the presence of increasing volumes of either whole serum or whole lymph obtained from subject 2. The data in Fig. 2 demonstrate that both whole serum and whole lymph contained material that

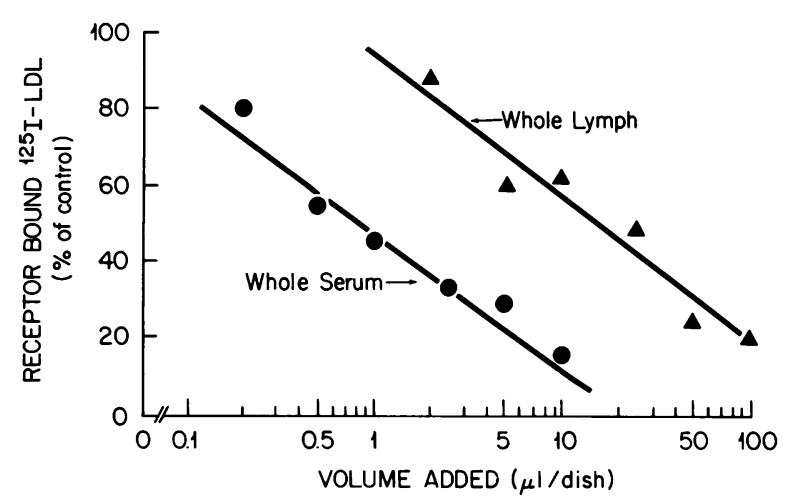

FIGURE 2 Comparison of the ability of whole serum (O) and whole lymph $(\Delta)$ to inhibit competitively the binding of ${ }^{125} \mathrm{I}$ LDL to the cell surface of normal fibroblast monolayers. The serum and lymph were obtained from subject 2. Fibroblasts were incubated with $2 \mu \mathrm{g} / \mathrm{ml}$ of ${ }^{125} \mathrm{I}-\mathrm{LDL}$ and the indicated amount of serum or lymph for $2 \mathrm{~h}$ at $4^{\circ} \mathrm{C}$ as described under Methods except that the serum and lymph specimens were not dialyzed into medium A. All samples were diluted to a $100-\mu \mathrm{l}$ volume in buffer $A$ before being added to the $0.5 \mathrm{ml}$ of growth medium in the culture dish. The amount of ${ }^{125} \mathrm{I}-$ LDL bound to the cells was determined as described under Methods. Each point for lymph was a single dish and each point for serum represents the average of duplicate dishes. The $100 \%$ of control value (mean of triplicate dishes) was $66 \mathrm{ng}$ of ${ }^{125} \mathrm{I}-\mathrm{LDL}$ bound per $\mathrm{mg}$ protein. competed with ${ }^{125}$ I-LDL for binding to the LDL receptor. The slopes of the competition lines were similar $(-35.6$ for whole serum and -37.9 for whole lymph). However, a 15-fold higher volume of whole lymph was required to achieve the same degree of competition as was obtained with a given volume of whole serum.

To determine whether the factor in whole lymph that suppressed HMG-CoA reductase activity was contained within the lipoprotein fraction, lymph samples from two subjects (3 and 4) were pooled and subjected to ultracentrifugation at a density of $1.063 \mathrm{~g} / \mathrm{ml}$. The lymph fraction of $d<1.063$ has been shown to contain nearly all of the apoprotein B immunoreactivity in whole lymph (12). The data in Fig. 3 demonstrate that the whole lymph suppressed enzyme activity by $90 \%$ when added to the culture medium at a concentration of $6 \mathrm{mg}$ protein $/ \mathrm{ml}$. The $d<1.063$ fraction was more than 500-fold more potent than whole lymph, $90 \%$ suppression of enzyme activity occurring at a $6-\mu \mathrm{g}$ protein $/ \mathrm{ml}$ concentration. In contrast, the lymph fraction of $d>1.063$, which contains high density lipoprotein as well as all other lymph proteins (10-12), did not suppress enzyme activity significantly when added to the culture medium at a concentration as high as $10 \mathrm{mg}$ protein $/ \mathrm{ml}$.

A sensitive index of the uptake of plasma LDL through the receptor mechanism in fibroblasts is the stimulation of cholesteryl ester formation as monitored by an increase in the rate of incorporation of $\left[{ }^{14} \mathrm{C}\right]$ oleate into cholesteryl $\left[{ }^{14} \mathrm{C}\right]$ oleate (23). Fig. 4 shows that whole lymph (pooled from subjects 3 and 4)

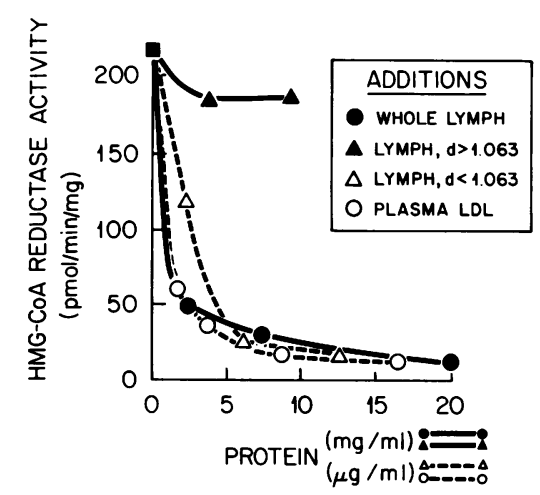

FIGURE 3 Ability of whole lymph and fractionated lymph to suppress HMG-CoA reductase activity in normal fibroblast monolayers. Lymph from subjects 3 and 4 was pooled and fractionated as described under Methods. Plasma LDL was obtained from a healthy subject and prepared in Dallas. The cells were incubated with the indicated amount of lipoprotein for $16 \mathrm{~h}$ at $37^{\circ} \mathrm{C}$. HMG-CoA reductase activity was determined as described under Methods. Each point represents a single dish. HMG-CoA reductase activity in the absence of any additions ( $\mathbf{D}$ ) was $220 \mathrm{pmol} / \mathrm{min}$ per $\mathrm{mg}$ protein (mean of triplicate dishes). 


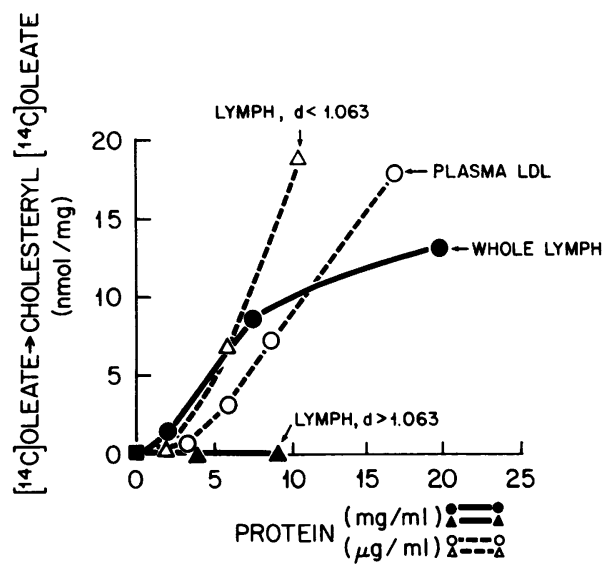

Figure 4 Ability of whole lymph and fractionated lymph to stimulate the incorporation of $\left[{ }^{14} \mathrm{C}\right]$ oleate into cholesteryl $\left[{ }^{14} \mathrm{C}\right]$ oleate in normal fibroblast monolayers. Lymph from subjects 3 and 4 was pooled and fractionated as described under Methods. Plasma LDL was obtained from a healthy subject and prepared in Dallas. The cells were incubated with the indicated amount of lipoprotein for $16 \mathrm{~h}$ at $37^{\circ} \mathrm{C}$ in the presence of $0.1 \mathrm{mM}\left[{ }^{14} \mathrm{C}\right]$ oleate. The cellular content of cholesteryl $\left[{ }^{14} \mathrm{C}\right]$ oleate was then determined as described under Methods. Each point represents a single dish. The cellular content of cholesteryl $\left[{ }^{14} \mathrm{C}\right]$ oleate in the absence of any additions $(\square)$ was $0.34 \mathrm{nmol} / \mathrm{mg}$ protein (mean of triplicate dishes).

markedly stimulated cholesteryl $\left[{ }^{14} \mathrm{C}\right]$ oleate formation in fibroblasts. When this lymph was fractionated by ultracentrifugation, all of the stimulatory activity was found in the fraction of $d<1.063$ and no activity was detected in the fraction of $d>1.063$.

To quantify the ability of the $d<1.063$ fraction of lymph to suppress HMG-CoA reductase and to compete with ${ }^{125} \mathrm{I}-\mathrm{LDL}$ for binding to the LDL receptor, lymph from individual subjects was fractionated and the volume of the $d<1.063$ fraction was readjusted to equal the volume of the original whole lymph sample. The results showed that the $d<1.063$ fraction of lymph from subject 5 suppressed HMG-CoA reductase activity in a manner parallel to that of whole serum. Moreover, the slope of the suppression line for the $d<1.063$ fraction of lymph $(-51.1)$ was similar to that obtained for whole lymph in Fig. 1 (-59.6). As with whole lymph, the suppression line for the $d<1.063$ fraction was displaced to the right by a factor of 10 as compared with the suppression line for whole serum from the same subject. A similar 10-fold volume difference was observed when the whole serum and $d<1.063$ fraction of lymph were tested in the competitive ${ }^{125}$ I-LDL binding assay (data not shown). These quantitative data confirmed that at least $90 \%$ of the LDL-like activity of lymph was localized to the $d<1.063$ fraction.

To confirm that the suppression of HMG-CoA reductase activity by whole lymph required binding of the lipoprotein to the LDL receptor, we compared the ability of whole lymph to suppress HMG-CoA reductase in cells from a normal subject and in cells from a patient with homozygous $F H$ which lack LDL receptors (22). Table II shows that whole lymph, when added to the normal cells at an apoprotein $B$ concentration of $15 \mu \mathrm{g} / \mathrm{ml}$ (as determined by immunoelectrophoresis), suppressed HMG-CoA reductase activity in the normal cells to $18 \%$ of the control value. On the other hand, in the FH homozygote cells, the same concentration of whole lymph produced an insignificant suppression of enzyme activity. In the same experiment, the addition of a mixture of 25hydroxycholesterol plus cholesterol, which suppresses HMG-CoA reductase activity in a manner independent of the LDL receptor $(4,5)$, suppressed enzyme activity by $95 \%$ in the $\mathrm{FH}$ homozygote cells.

Fig. 5 shows the suppression of HMG-CoA reductase activity by increasing amounts of whole lymph from two additional subjects (6 and 7). The data are plotted as a function of the amount of apoprotein $B$ added to the culture medium as calculated from the apoprotein B concentration of the lymph specimens as determined by immunoelectrophoresis. The results for the two whole lymph samples are compared with those of isolated serum LDL obtained from the same two subjects and with a standard plasma LDL preparation isolated in Dallas. The apoprotein B concentration of the standard plasma and the two serum LDL

TABLE II

Impaired Ability of Whole Lymph to Suppress HMG-CoA Reductase Activity in FH Homozygote Fibroblasts

\begin{tabular}{|c|c|c|}
\hline \multirow[b]{2}{*}{ Addition to medium } & \multicolumn{2}{|c|}{$\begin{array}{l}\text { HMG-CoA reductase activity/ } \\
(\mathrm{pmol} / \mathrm{min} \text { per mg protein) }\end{array}$} \\
\hline & $\begin{array}{l}\text { Normal } \\
\text { cells }\end{array}$ & $\begin{array}{c}\text { FH } \\
\begin{array}{c}\text { Homozygote } \\
\text { cells }\end{array}\end{array}$ \\
\hline & $\%$ & $\%$ \\
\hline None & $266(100)^{*}$ & $369(100)^{*}$ \\
\hline Plasma LDL (15 $\mu$ g protein $/ \mathrm{ml})$ & $25 \quad(9.4)$ & $312(85)$ \\
\hline $\begin{array}{l}\text { Whole lymph (15 } \mu \mathrm{g} \text { apoprotein } \\
\text { B/ml) }\end{array}$ & $48 \quad(18)$ & $318(86)$ \\
\hline $\begin{array}{l}\text { 25-Hydroxycholesterol }(1 \mu \mathrm{g} / \mathrm{ml}) \\
+ \text { Cholesterol }(10 \mu \mathrm{g} / \mathrm{ml})\end{array}$ & - & (5.4) \\
\hline
\end{tabular}

Plasma LDL was obtained from a healthy subject and prepared in Dallas. Whole lymph was obtained from subject 6 . Incubations were carried out for $16 \mathrm{~h}$ at $37^{\circ} \mathrm{C}$. Enzyme assays were performed as described under Methods except that all dishes received $3 \mu \mathrm{l}$ of ethanol. The ethanol was used to deliver the mixture of 25-hydroxycholesterol plus cholesterol. Each value represents the average of duplicate dishes except for the whole lymph values, which were single dishes.

* Numbers in parentheses represent the percent of control HMG-CoA reductase activity. 


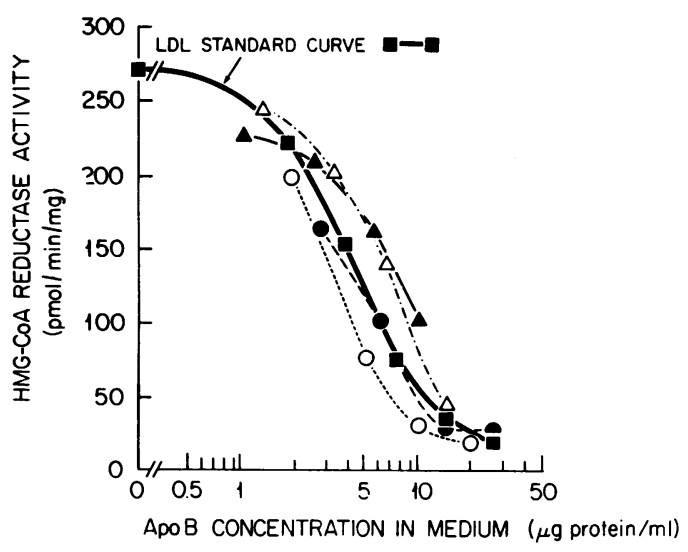

FIGURE 5 Suppression of HMG-CoA reductase activity in normal fibroblast monolayers by whole lymph $(\Delta, \Delta)$ and serum LDL $(\Theta, O)$ as a function of the concentration of apoprotein $B$ in the culture medium. The plasma used for the standard curve $(\square-\square)$ was obtained from a healthy subject and prepared in Dallas. Subject $6(O, \triangle)$ and subject $7(O, \Delta)$ served as sources for the whole lymph and serum LDL. The apoprotein B content of the whole lymph specimens was determined by immunoelectrophoresis and the apoprotein B content of the plasma and serum LDL samples was determined by the Lowry method. The cells were incubated with the lipoproteins for 16 $h$ at $37^{\circ} \mathrm{C}$ as described under Methods. Each value represents a single dish. HMG-CoA reductase activity in the absence of any additions was $266 \mathrm{pmol} / \mathrm{min}$ per $\mathrm{mg}$ protein (mean of triplicate dishes).

samples was measured using the Lowry method, assuming that all of the protein was apoprotein B. In general, both samples of whole lymph and serum LDL suppressed HMG-CoA reductase within the same range of apoprotein $B$ concentrations and the slopes for these curves were similar to that of the standard plasma LDL. However, the curves for the two whole lymph specimens were displaced slightly to the right of the curves for serum LDL, suggesting that a somewhat larger amount of apoprotein B-containing lipoproteins were necessary to achieve a given degree of enzyme suppression when the lipoproteins were added in whole lymph as compared with serum LDL. Whether this slight decrease in biological activity of lymph apoprotein B is related to technical considerations involved in the shipment and dialysis of the lymph, or whether it represents a true biological difference, remains to be determined.

In an additional study, we compared the ability of whole lymph and plasma LDL to compete with ${ }^{125} \mathrm{I}$ LDL for total cell binding (receptor-bound plus internalized) and proteolytic degradation at $37^{\circ} \mathrm{C}$ (14). The whole lymph and plasma samples competed similarly when added at the same apoprotein B concentration. For example, when ${ }^{125}$ I-LDL $(20 \mu \mathrm{g}$ protein $/ \mathrm{ml}$ ) was incubated with fibroblast monolayers for $6 \mathrm{~h}$ at $37^{\circ} \mathrm{C}$, the control values for total cell binding and degradation of ${ }^{125}$ I-LDL were 1,520 and 7,360 $\mathrm{ng} / \mathrm{mg}$ cell protein, respectively. The amount of ${ }^{125}$ I-LDL bound and degraded was reduced to $40 \%$ of the control values when either standard plasma LDL or whole lymph obtained from subject five was included in the incubation medium at an apoprotein B concentration of $70 \mu \mathrm{g} / \mathrm{ml}$.

\section{DISCUSSION}

The current studies demonstrate the presence in lymph from the human foot of a lipoprotein with biologic activity similar to that of plasma LDL. This activity was detected by functional assays that depend on the ability of lymph lipoproteins to bind to the LDL receptor in human fibroblasts $(4,5)$. Thus, the addition of whole lymph to fibroblast monolayers that had been incubated in the absence of lipoproteins led to a suppression of HMG-CoA reductase activity and a stimulation of the incorporation of $\left[{ }^{14} \mathrm{C}\right]$ oleate into cholesteryl $\left[{ }^{14} \mathrm{C}\right]$ oleate. In addition, whole lymph contained material that competitively inhibited the binding of ${ }^{125}$ I-LDL to the surface LDL receptor of fibroblasts.

With these assays, it was possible to show that all of the detectable LDL-like activity was contained in the fraction of whole lymph of $d<1.063$. Furthermore, significant suppression of HMG-CoA reductase activity was not observed when whole lymph was added to fibroblasts from a subject with homozygous $\mathrm{FH}$, supporting the conclusion that suppression of enzyme activity by lymph required binding of the lymph lipoprotein to the LDL receptor.

The concentration of LDL-like activity in whole lymph or in its $d<1.063$ fraction was found to be $\cong 10 \%$ of the concentration in whole serum. These findings are in agreement with previous immunological data showing that the concentration of apoprotein $B$ in lymph is $\cong 1 / 10$ th that in serum and that nearly all of this activity is present in the $d<1.063$ fraction (12). Moreover, the current functional measurements are also consistent with the observations that the lymph/serum ${ }^{131} \mathrm{I}-\mathrm{LDL}$ concentration ratio reaches a value of $\cong 1 / 10$ th at $14 \mathrm{~h}$ after an intravenous injection of ${ }^{131} \mathrm{I}-\mathrm{LDL}(11)$ and that in a given subject the concentration of cholesterol in whole lymph is $\cong 1 / 10$ th that in the serum (10-12).

The data in this paper, considered together with the previous measurements cited earlier, strongly suggest that the lipoprotein in human lymph that binds to the LDL receptor and delivers cholesterol to cells is LDL. Although the triglyceride-rich plasma lipoprotein very low density lipoprotein (VLDL) also contains apoprotein B (13) and may interact with the LDL receptor $(14,21)$ and suppress HMG-CoA reductase activity in fibroblasts (19), it is unlikely that the activity measured in the current studies is due to 
VLDL. Studies have shown that the vast bulk of immunoreactive apoprotein $B$ in lymph is found in the $d$ 1.019-1.063 fraction [LDL] and very little is present in the $d<1.006$ fraction [VLDL] (12). Moreover, the triglyceride concentration in lymph is very low and is not correlated with the plasma VLDL level (10). In addition to human LDL and VLDL, animal lipoproteins (such as $\left.\mathrm{HDL}_{c}\right)^{3}$ that contain the argininerich protein also bind to the human fibroblast LDL receptor $(26,27)$. Normal human plasma, however, contains only small amounts of the arginine-rich protein and that which is present is found predominantly in the triglyceride-rich VLDL fraction $(28,29)$.

The 10 to 1 concentration gradient between LDL activity in plasma and dorsal foot lymph for man is consistent with Grotte's data using dextran particles in which the concentration ratio between plasma and lymph in the dog paw was $\cong 10$ to 1 for molecules with a mol wt $>2 \times 10^{4}(8)$. The finding of a similar 10 to 1 plasma to lymph concentration gradient for human LDL and inert macromolecules strongly suggests that the transport of LDL from plasma to lymph occurs as a result of passive movement across the capillary endothelium and does not require a specific (i.e., receptormediated) transport process. Moreover, in a previous study it was noted that the plasma to lymph cholesterol ratio was 10 to $1(700 \mathrm{vs} .70 \mathrm{mg} / \mathrm{dl})$ in a subject with homozygous FH (10). This finding suggests that the LDL receptor described for fibroblasts, smooth muscle cells, and lymphocytes does not play a role in the transendothelial transport of LDL in capillaries of the foot. Because this receptor is functionally absent in the cells of such FH homozygotes, these subjects would be expected to have a decreased plasma to lymph cholesterol ratio if the LDL receptor were necessary to transport LDL across the endothelium.

It should be emphasized that the studies reported herein were confined to lymph obtained from the dorsum of the human foot. From studies in animals, it is known that lymph from internal organs, such as the liver and the intestine, exhibits a different composition from that of peripheral tissues, especially with regard to the concentration of macromolecules (6). Nonetheless, the presence of a 10 to 1 gradient between plasma and lymph for LDL may provide a partial explanation for the high affinity of the LDL receptor present on human fibroblasts and other cell types.

\section{ACKNOWLEDGMENTS}

Gloria Y. Brunshcede and Linda Letzig provided excellent technical assistance. We thank Marian Eastman and Carol Mansen for their help with the tissue culture.

This research was supported by a grant from the National Institutes of Health (HL 16024).

${ }^{3} \mathrm{HDL}_{\mathrm{c}}$, a distinctive lipoprotein with $\alpha$ mobility occurring in cholesterol-fed animals.

\section{REFERENCES}

1. Schneider, R. J., R. L. Burger, C. S. Mehlman, and R. H. Allen. 1976. The role and fate of rabbit and human transcobalamin II in the plasma transport of vitamin $B_{12}$ in the rabbit. J. Clin. Invest. 57: 27-38.

2. Youngdahl-Turner, P., R. H. Allen, and L. E. Rosenberg. 1977. Binding and uptake of transcobalamin II by human fibroblasts. Clin. Res. 25: 472A. (Abstr.)

3. Kailis, S. G., and E. H. Morgan. 1974. Transferrin and iron uptake by rabbit bone marrow cells in vitro. Br. J. Haematol. 28: 37-52.

4. Brown, M. S., and J. L. Goldstein. 1976. Receptor-mediated control of cholesterol metabolism. Science (Wash. D.C.). 191: 150-154.

5. Goldstein, J. L., and M. S. Brown. 1976. The LDL pathway in human fibroblasts: a receptor-mediated mechanism for the regulation of cholesterol metabolism. Curr. Top. Cell. Regul. 11: 147-181.

6. Yoffey, J. M., and F. C. Courtice, editors. 1970. Lymphatics, Lymph and the Lymphomyeloid Complex. Academic Press Inc., Ltd., London. 1-868. pp.

7. Crone, C., and N. A. Lassen, editors. 1969. Capillary Permeability. Academic Press, Inc. New York. 15-669.

8. Grotte, G. 1956. Passage of dextran molecules across the blood-lymph barrier. Acta Chir. Scand. Suppl. 211: 1-84.

9. Renkin, E. M. Permeability and molecular size in peripheral and glomerular capillaries. 1969. In Capillary Permeability. C. Crone, and N. A. Lassen, editors. Academic Press, Inc. New York. 544-547.

10. Reichl, D., L. A. Simons, N. B. Myant, J. J. Pflug, and G. L. Mills. 1973. The lipids and lipoproteins of human peripheral lymph, with observations on the transport of cholesterol from plasma and tissues into lymph. Clin. Sci. Mol. Med. 45: 313-329.

11. Reichl, D., A. Postiglione, N. B. Myant, J. J. Pflug, and M. Press. 1975. Observations on the passage of apoproteins from plasma lipoproteins into peripheral lymph in two men. Clin. Sci. Mol. Med. 49: 419-426.

12. Reichl, D., N. B. Myant, and J. J. Pflug. 1977. Concentration of lipoproteins containing apolipoprotein $\mathrm{B}$ in human peripheral lymph. Biochim. Biophys. Acta. 489: 98-105.

13. Jackson, R. L., J. D. Morisett, and A. M. Gotto, Jr. 1976. Lipoprotein structure and metabolism. Physiol. Rev. 56: 259-316.

14. Goldstein, J. L., and M. S. Brown. 1974. Binding and degradation of low density lipoproteins by cultured human fibroblasts: comparison of cells from a normal subject and from a patient with homozygous familial hypercholesterolemia. J. Biol. Chem. 249: 5153-5162.

15. Goldstein, J. L., S. K. Basu, G. Y. Brunschede, and M. S. Brown. 1976. Release of low density lipoprotein from its cell surface receptor by sulfated glycosaminoglycans. Cell. 7: 85-95.

16. Ho, Y. K., M. S. Brown, D. W. Bilheimer, and J. L. Goldstein. 1976. Regulation of low density lipoprotein receptor activity in freshly isolated human lymphocytes. J. Clin. Invest. 58: 1465-1474.

17. Goldstein, J. L., and M. S. Brown. 1977. The low density lipoprotein pathway and its relation to atherosclerosis. Annu. Rev. Biochem. 46: 897-930.

18. Havel, R. J., H. A. Eder, and J. H. Bragdon. 1955. The distribution and chemical composition of ultracentrifugally separated lipoproteins in human serum. J. Clin. Invest. 34: 1345-1353.

19. Brown, M. S., S. E. Dana, and J. L. Goldstein. 1974. Regulation of 3-hydroxy-3-methylglutaryl coenzyme A reduc- 
tase activity in cultured human fibroblasts: Comparison of cells from a normal subject and from a patient with homozygous familial hypercholesterolemia. J. Biol. Chem. 249: 789-796.

20. Brown, M. S., and J. L. Goldstein. 1974. Suppression of 3-hydroxy-3-methylglutaryl coenzyme A reductase activity and inhibition of growth of human fibroblasts by 7-ketocholesterol. J. Biol. Chem. 249: 7306-7314.

21. Brown, M. S., and J. L. Goldstein. 1974. Familial hypercholesterolemia: defective binding of lipoproteins to cultured fibroblasts associated with impaired regulation of 3-hydroxy-3-methylglutaryl coenzyme A reductase activity. Proc. Natl. Acad. Sci. U.S.A. 71: 788-792.

22. Brown, M. S., and J. L. Goldstein. 1976. Familial hypercholesterolemia: A genetic defect in the low-density lipoprotein receptor. N. Engl. J. Med. 294: 1386-1390.

23. Goldstein, J. L., S. E. Dana, and M. S. Brown. 1974. Esterification of low density lipoprotein cholesterol in human fibroblasts and its absence in homozygous familial hypercholesterolemia. Proc. Natl. Acad. Sci. U.S.A. 71: 4288-4292.
24. Lowry, O. H., N. J. Rosebrough, A. L. Farr, and R. J. Randall. 1951. Protein measurement with the Folin phenol reagent. J. Biol. Chem. 193: 265-275.

25. Blomhoff, J. P. 1973. Serum cholesterol determination by gas-liquid chromatography. Clin. Chim. Acta. 43: 257265.

26. Bersot, T. P., R. W. Mahley, M. S. Brown, and J. L. Goldstein. 1976. Interaction of swine lipoproteins with the low density lipoprotein receptor in human fibroblasts. J. Biol. Chem. 251: 2395-2398.

27. Mahley, R. W., and T. L. Innerarity. 1977. Interaction of canine and swine lipoproteins with the low density lipoprotein receptor of fibroblasts as correlated with heparin/ manganese precipitability. J. Biol. Chem. 252: 39803986.

28. Havel, R. J., and J. P. Kane. 1973. Primary dysbetalipoproteinemia: Predominance of a specific apoprotein species in triglyceride-rich lipoproteins. Proc. Natl. Acad. Sci. U.S.A. 70: 2015-2019.

29. Shelburne, F. A., and S. H. Quarfordt. 1974. A new apoprotein of human plasma very low density lipoproteins. $J$. Biol. Chem. 249: 1428-1433. 